\title{
TALKING ABOUT SEXUALITY, STI AND AIDS WITH POOR ADOLESCENTS
}

\author{
Juliana Kelli Murakami ${ }^{1}$ \\ José Fernando Petrilli Filho ${ }^{2}$ \\ Paulo Celso Prado Telles Filho ${ }^{3}$
}

Murakami JK, Petrilli Filho JF, Telles Filho PCP. Talking about sexuality, STI and Aids with poor adolescents. Rev Latino-am Enfermagem 2007 setembro-outubro; 15(número especial):864-66.

This study aimed to report an educative action experience on sexuality/STI/Aids in an adolescent group living in a poor context. The study site was a Family Health Unit located in a city in the interior of São Paulo, Brazil. Six female adolescents participated in the educative actions, and each of the five meetings took 70 minutes on the average. The educative action allowed for knowledge/action based on a network of interlaced gestures, words and affections, permeating new constructions. Thus, new meanings emerged, not only for the adolescents, who discovered the power of being in the group, but also for the researchers, who managed to visualize other horizons for the work with highly vulnerable groups in society.

DESCRIPTORS: group structure; health education; family health program; adolescent; poverty

\section{CONVERSANDO SOBRE SEXUALIDAD, IST Y SIDA CON ADOLESCENTES POBRES}

La finalidad de este estudio fue relatar la experiencia de una acción educativa sobre sexualidad/IST/ Sida en un grupo de adolescentes en contexto de pobreza. El sitio del estudio fue una Unidad de Salud de la Familia ubicada en un municipio del interior del estado de São Paulo, Brasil. La acción educativa les involucró a seis adolescentes del sexo femenino, y cada uno de los cinco encuentros tuvo duración promedia de 70 minutos. La acción educativa posibilitó un saber/hacer a partir de una red de gestos, palabras y afectos que se entrelazaron, permeando nuevas construcciones. Así, nacieron nuevos sentidos, no sólo para las adolescentes, que descubrieron la fuerza de ser/estar en el grupo, pero también para los investigadores que lograron visualizar otros horizontes para el trabajo en comunidades de alta vulnerabilidad social.

DESCRIPTORES: estructura de grupo; educación en salud; programa salud de la familia; adolescente; pobreza

\section{CONVERSANDO SOBRE SEXUALIDADE, IST E AIDS COM ADOLESCENTES POBRES}

O presente estudo objetivou relatar a experiência de uma ação educativa sobre sexualidade/IST/Aids junto a um grupo de adolescentes em contexto de pobreza. O local do estudo foi uma Unidade de Saúde da Família localizada em um município do interior paulista. A ação educativa contou com a participação de seis adolescentes do sexo feminino, e cada um dos cinco encontros teve duração média de 70 minutos. $A$ ação educativa possibilitou um saber/fazer a partir de uma rede de gestos, palavras e afetos que se entrelaçaram, permeando novas construções. Assim, nasceram novos sentidos, não apenas para as adolescentes, que descobriram a força de ser/estar no grupo, mas também para os pesquisadores que conseguiram visualizar horizontes outros para o trabalho em comunidades de alta vulnerabilidade social.

DESCRITORES: estrutura de grupo; educação em saúde; programa saúde da família; adolescente; pobreza

${ }^{1}$ Graduate Student in Nursing; Advisor, Occupational Health Nurse, M.Sc. in Psychiatric Nursing, Professor. São Carlos Federal University, Brazil, e-mail: jfpetrilli@uol.com.br; ${ }^{3}$ Nurse, PhD in Fundamental Nursing, Professor, Federal University dos Vales do Jequitinhonha e Mucuri, Brazil 


\section{INTRODUCTION}

In Brazil, for over 20 years of AIDS epidemic, deep changes are observed regarding the transmission dynamics of the Human Immunodeficiency Virus (HIV). Nowadays, the epidemic presents increments among heterosexuals, women, young people, individuals with low education levels and income. This portrait no longer points towards specific groups or behaviors; rather, it points to a tangle of variables, certainly more complex and intricate than what was thought at the beginning of the epidemic ${ }^{(1)}$.

Currently, a significant increase in the infection among heterosexuals (particularly women), accompanied by the expansion of the epidemic among individuals with low education levels, as well as in small municipalities, favors the emergence of the concept of vulnerability.

This concept is both a construct and constructor of a broadened and reflexive perception that identifies the ultimate reasons of the epidemic as well as its impacts, which range from organic susceptibilities to how health programs are structured, going through behavioral, cultural, economic and political aspects ${ }^{(2)}$.

The World Health Organization (WHO) estimates that approximately $50 \%$ of new HIV infections in the world occur during adolescence ${ }^{(3)}$.

In adolescence, aspects associated to sexuality assume a key position in teenagers' lives. It is mandatory that parents, teachers and health team professionals, who are part of the universe of relationships with the referred subjects, contribute to people's healthy development ${ }^{(4)}$.

HIV infection has a complex relationship with poverty, although it affects both rich and poor ${ }^{(5)}$.

The relevance of educational problems involving adolescents in a context of poverty has been pointed out, since most appear to be more susceptible to behaviors that favor the transmission of Sexually Transmissible Diseases (STD) ${ }^{(6)}$.

Due to the limited portrait, this study aimed to report on the experience of an educative action about sexuality/STI (Sexually Transmissible Infections)/AIDS with a group of adolescents in a context of poverty.

\section{THE PLACE OF STUDY AND THE OPERATIONALIZATION OF A CONTEXT OF POVERTY}

The place of study was a Family Health Unit (FHU) located in a municipality in the interior of São
Paulo State. This health service is located in an area of high social vulnerability, according to the Índice Paulista de Vulnerabilidade Social (IPVS) [The São Paulo Social Vulnerability Index].

The IPVS was established in the year 2000, resulting from a request by the Sao Paulo State Legislative Assembly to the Fundação Seade [State Data Analysis System Foundation], and correlates individual and family characteristics, such as life cycle, type of family arrangement, education level, current income, forms of entering the job market, health conditions, and their possibilities of benefiting from assets and services provided by the State, society and market, classifying them in social vulnerability groups (1-no vulnerability, 2-very low vulnerability, 3-low vulnerability, 4-medium vulnerability, 5-high vulnerability, and 6-very high vulnerability $)^{(7)}$.

\section{THE EDUCATIONAL ACTION AND THE CONTEXT OF POVERTY: THE SEARCH FOR POSSIBILITIES}

We adopted the Systemic Thought and the Operative Group as the Theoretical and Methodological Framework.

Six adolescent girls participated in the educational action, and each meeting lasted an average of 70 minutes. A nurse with specialization in Operative Groups, a nursing undergraduate, and a nurse from the Family Health Unit (of two meetings) took part in the activity.

In this context, we also sought an articulation between the Sao Carlos Federal University and the USF, with a view to providing feedback to the production, consumption and knowledge usage processes.

Hence, we aimed for a partnership between nurse teachers, staff nurses and health institutions in every research stage, with a view to not only producing or communicating or using, but to produce, communicate and use nursing research ${ }^{(8)}$.

In this setting, we also highlight the educational action, which permitted knowledge/action based on a network of gestures, words and attachments that were intertwined and permeated new constructions.

We were surprised to find out the number of possibilities that can emerge from one question. The many words one word can have ${ }^{(9)}$. The richness that can be involved in the context of poverty. 
At each meeting, a discovery, a new story that emerged among timid smiles and hopeful looks from the adolescents. The discourse that invited to a new way of thinking, feeling and acting spoke about a different form of learning, in which it is possible to be the protagonist.

At each picture, body, pleasure and STI/AIDS were explored by the groups from stories and ideas brought by the adolescents. The embarrassment to speak slowly gave way to the idea of the group as a sober space, in which listening, attachment and welcoming have fundamental roles in learning to learn.

For the researchers, the group's discovery as a space of systemic and circular construction showed how it can be inspiring and revealing for nurses' work, since it permitted the emergence of a practice converging with the sociocultural context at stake.
Hence, new senses emerged, not only for the adolescents, who discovered the strength of composing/ being in the group, but also for the researchers, who were able to visualize new horizons for working in communities with high social vulnerability levels.

\section{FINAL CONSIDERATIONS}

We observed that the IPVS resizes and puts in practice a new concept for poor and poverty, allowing for the emergence of a conceptual outline for innovating practices, contextualized and empowered in contexts of social vulnerability.

We also highlight our desire that, through experience reports like this one, nurses will feel invited to overcome models that are merely instructive and advance towards an affective and dialogic practice in their work context.

\section{REFERENCES}

1. Petrilli JF Filho, Bueno SMV. Vulnerabilidade às IST/Aids entre atiradores do serviço militar obrigatório: uma apreciação sociocomportamental. Cogitare Enfermagem 2006 setembro; 11(3):218-25.

2. Ayres JRCM, França Júnior I, Calazans GJ, Saletti HC Filho. O conceito de vulnerabilidade e as práticas de saúde: novas perspectivas e desafios. In: Czeresnia D, Freitas CM, organizadores. Promoção da saúde: conceitos, reflexões, tendências. Rio de Janeiro (RJ): Fiocruz; 2003. p.117-39.

3. Jeolás LS, Ferrari RAP. Oficina de prevenção em um serviço de saúde para adolescentes: espaço de reflexão e de conhecimento compartilhado. Rev Ci Saúde Coletiva 2003 janeiro; 8(2):611-20.

4. Medeiros M, Ferriani MGC, Munari DB, Gomes R. A sexualidade para o adolescente em situação de rua em Goiânia. Rev Latino-am. Enfermagem 2001 março; 9(2):35-41.

5. Muniyandi M, Ramachandran R, Balasubramanian R. An economic commentary on the occurrence and control of HIV/ AIDS in developing countries: special reference to India. Expert Opin Pharmacother 2006 December; 7(18):2447-54.

6. Silva PDB, Oliveira MDS, Matos MA, Tavares VR, Medeiros M, Brunini S, Teles SA. Comportamentos de risco para as doenças sexualmente transmissíveis em adolescentes escolares de baixa renda. Rev Eletrônica Enfermagem 2005; 7(2):185-9.

7. SEADE. Fundação Sistema Estadual de Análise de Dados. Índice Paulista de Vulnerabilidade Social. [on line] [citado 2006 july 30]. Disponível em: URL: http://www.seade.gov.br/ produtos/ipvs/apresentacao.php.
8. Mendes IAC. Pesquisa em enfermagem: impacto na prática. São Paulo (SP): Sarvier; 1991.

9. Andersen T. Processos Reflexivos. 2. ed. Rio de Janeiro (RJ): Instituto NOOS; 2002. 